\title{
Histone Deacetylase 6
}

National Cancer Institute

\section{Source}

National Cancer Institute. Histone Deacetylase 6. NCI Thesaurus. Code C19679.

Histone deacetylase 6 (1215 aa, $131 \mathrm{kDa}$ ) is encoded by the human HDAC6 gene. This protein plays a role in the unfolded protein response, cell motility and the deacetylation of both histones and tubulin. 